\title{
结合微树芯方法的树木生长生理生态学研究进展
}

\author{
郭霞丽 $1,2,3$ 余碧云 $1,2,3$ 梁寒雪 1,3 黄建国 ${ }^{1,3 *}$ \\ ${ }^{1}$ 中国科学院华南植物园退化生态系统植被恢复与管理重点实验室, 广州 $510650 ;{ }^{2}$ 中国科学院大学, 北京 $100049 ;{ }^{3}$ 中国科学院华南植物园广东省应 \\ 用植物学重点实验室, 广州 510650
}

\begin{abstract}
摘 要 近年来迅速发展的微树芯技术(micro-sampling approach)通过每周采集树干木质部的微样芯，并制作生物切片来实时 监测整个生长季的树干形成层细胞分裂活动以及木质部的形成过程。与传统的树木年轮学方法相比, 微树芯技术能从一个更 微观、更准确的角度探索树木内在生理过程及树木生长对外界环境的响应。该文概述了微树芯技术的发展历程和应用前景, 并结合国内外研究来阐述利用树木微树芯技术研究树木初级生长和次级生长及其关系, 以及在全球变化(升温、干旱以及碳、 氮增肥效应)背景下树木年内径向生长的响应机制, 为进一步预测森林生产力和固碳潜力以及实现可持续林业经营管理的政 府决策提供科学依据。
\end{abstract}

关键词＼cjkstart微树芯技术; 径向生长; 木质部; 形成层; 气候变化

引用格式: 郭霞丽, 余碧云, 梁寒雪, 黄建国 (2017). 结合微树芯方法的树木生长生理生态学研究进展. 植物生态学报, 41, 795-804. doi: $10.17521 /$ cjpe.2017.0009

\section{Advancement in studies of tree growth and ecophysiology incorporating micro-sampling approach}

\author{
GUO Xia-Li ${ }^{1,2,3}$, YU Bi-Yun ${ }^{1,2,3}$, LIANG Han-Xue ${ }^{1,3}$, and HUANG Jian-Guo ${ }^{1,3^{*}}$ \\ ${ }^{1}$ Key Laboratory of Vegetation Restoration and Management of Degraded Ecosystems, Chinese Academy of Sciences, Guangzhou 510650, China; ${ }^{2}$ University \\ of Chinese Academy of Sciences, Beijing 100049, China; and ${ }^{3}$ Guangdong Provincial Key Laboratory of Applied Botany, South China Botanical Garden, \\ Chinese Academy of Sciences, Guangzhou 510650, China
}

\section{Abstract}

The recently developed micro-sampling approach has been widely used to extract micro-tree-cores at weekly intervals to monitor the process of stem cambial activity and xylem formation. Compared with the traditional dendrochronology, the micro-sampling approach enables us to better understand the inherent physiological processes in tree growth and their relationships with the environment at a more precise level. This review article aims to: 1) summarize the progresses in the micro-sampling approach-based studies published over recent years and its potential applications, and 2) elucidate the relationships between primary growth and secondary growth and the response mechanisms of radial growth of trees to global change (global warming, drought, and carbon and nitrogen fertilization effects) based on information from literature. It is anticipated that this review will assist with predicting productivity and carbon sink potential of forests, and help policy-makers with sustainable forest management decisions.

Key words micro-sampling approach; radial growth; xylem; cambium; climate change

Citation: Guo XL, Yu BY, Liang HX, Huang JG (2017). Advancement in studies of tree growth and ecophysiology incorporating micro-sampling approach. Chinese Journal of Plant Ecology, 41, 795-804. doi: 10.17521/cjpe.2017.0009

森林生态系统对减缓气候变暖有重要作用, 它 不仅是地球上重要的碳汇, 而且也是宝贵的资源库, 因此研究其生理过程和生态作用非常重要。树木年 轮是树木周期性生长的一种表现形式。由于树木年 轮具有定年准确、样本容易获得等优点 (吴祥定, 1990; Speer, 2010)而被广泛利用，包括通过树轮重
建来研究大空间尺度、长时间尺度上的温度和降水 变化(Mann et al., 2008; Shao et al., 2010; Yang et al., 2014)、全球变化背景下的森林生态系统变化(王晓 春等, 2011; 于健等, 2016)以及人文、水文(Gou et al., 2010; Wang \& Zhao, 2013)等方面。然而, 现阶段树 木年轮学研究多集中在高海拔、高纬度, 以及干旱

收稿日期Received: 2017-01-17 接受日期Accepted: 2017-04-17

* 通信作者Author for correspondence (E-mail: huangjg@scbg.ac.cn) 
半干旱等树木年轮易鉴别的地区。在热带、亚热带 地区，树木连续或间断的生长方式导致年轮界限不 清楚, 传统的树木年轮学方法难以准确定年 (Zalamea et al., 2013)。此外, 树木在一个生长季中 不同时期的限制因子可能有所差异, 生长速率不尽 相同，因此用年际间的树轮宽度很难准确地反映真 实的环境信息以及树木生长状况。Seo等(2011)研究 表明, 气候和树木生长的关系在年际间尺度和年内 尺度上可能有所差异, 需要通过更精细的方法探讨 树木径向生长动态及其对周围环境的响应情况。

分辨率更高、测量更精细的方法需要通过时间 上连续监测来实现。目前监测树木径向生长的传统 方法是使用树木径向生长测量仪(Mäkinen et al., 2003; Drew \& Downes, 2009), 该方法可以提供树木 茎干周长变化的高精度时间序列, 从而探索树木生 长对外界环境的响应。董满宇等(2012)通过树木径 向生长测量仪监测了山西省芦芽山林线组成树种白 扞(Picea meyeri)生长季内树木径向生长动态, 发现 6月末白扞径向生长速度达到最大值, 生长速度主 要受光周期的影响。然而树木茎干周长变化包含了 茎干本身受水分影响导致的伸缩和扩张波动以及形 成层细胞分裂和新形成的木质部和韧皮部的细胞增 大等情况(Deslauriers et al., 2003), 且不能通过有效 的方法准确区分出细胞生长的变化(Mäkinen et al., 2003), 因此在研究树木形成层以及木质部生长方 面存在局限性。Wolter (1968)开创了针刺创伤法 (pinning method), 可以通过直接观察形成层受损伤 后附近新形成的细胞数量和大小来准确记录细胞生 长的物候。例如, Seo等(2011)利用针刺创伤法监测 了芬兰北部森林欧洲赤松(Pinus sylvestris)从2000年 到2004年的木质部生长过程, 发现径向生长集中在 6 月中旬到7月中旬之间, 与生长季开始的时间无 关。Eilmann等(2011)对比研究了不同水分条件下欧 洲赤松的生长情况, 发现相比于灌溉条件下的欧洲 赤松, 干旱条件下的欧洲赤松生长季明显缩短, 且 径向生长量明显降低。同时, 运输水分的管胞细胞 壁更薄, 细胞更大, 具有更高的水分利用效率, 体 现了对干旱环境的适应性。然而在生长季监测期结 束时, 需要利用業子取出受伤的和新生长的组织进 行进一步的实验室研究, 对树木伤害较大(Mäkinen et al., 2003; 何敏慧和杨保, 2014)。与此同时, 微树 芯技术逐步发展, 该技术通过专业的工具每隔一定
时间从树干上取出包括韧皮部、形成层和木质部在 内的微小树芯, 经过实验室生物切片制作再现了形 成层从休眠到分裂以及产生木质部的全过程 (Antonova \& Stasova, 1993)。由于通过微树芯技术采 取的树芯微小, 对树木损伤小, 并且可以持续采集 微树芯，因此该技术近年来发展迅速。Deslauries等 (2003)最先在加拿大东部北方针叶林中用外科医用 骨髓针连续监测了Abies balsamea从1998到2000年 间 3 个生长季的木质部形成过程, 并创新性地定量 了该树种木质部早材和晚材生长开始和结束的时间, 以及它们的整个生长过程。使用外科医用骨髓针在 取出微样芯的过程中会造成新生细胞挤压和破损, 并且微样芯表面容易产生裂痕, 为后续的生物切片 带来不便。为解决这一问题, 2004年, 微型生长雉 Trephor (图1, 专利号PD2004A000324)在意大利被 研发, 通过使用锤子将生长雉前端的切管插入树干 中, 取出直径1.5-2.0 $\mathrm{mm}$ 的微小树芯通过进一步的 生物切片进行研究。Mäkinen等(2008)对欧洲云杉 (Picea abies)和欧洲赤松同时采取3种采样方法进行 比较, 发现针刺创伤法和微树芯技术监测到的树木 产生的管胞总数相同, 而树木径向生长测量仪在春 天早期显示了树干周长的明显增大，但通过针刺创 伤法和微树芯技术均未检测到树干细胞的形成, 说 明针刺创伤法和微树芯都是监测木质部活动的可靠 的技术。运用微树芯技术在树木茎干连续采样(图2), 既减小了对树木的伤害, 又能获得高质量的样品, 因此得以推广运用(Rossi et al., 2006)。

目前微树芯技术在国内外得到重视并且方法 日益成熟(Rossi et al., 2006; 张军周等, 2013), 极大 地推进了对树干形成层活动及木质部形成过程方 面的详细研究。通过微树芯技术可以监测形成层以 及木质部的发育过程, 以及通过模型定量出形成 层活动开始和结束的具体时间以及细胞分裂的速 率(Huang et al., 2011, 2014; Zhai et al., 2012; Cuny et al., 2014; Lupi et al., 2014), 详细记录树木木质 部的生长动态, 进一步预测树木的生长情况(Bigler et al., 2004), 权衡探索树木的生存策略(Cuny et al., 2012; del Castillo et al., 2016), 了解树木的生 活型(Xiao et al., 2014), 估算森林碳储量(Cuny et al., 2015)等。在法国东北部生长的先锋树种欧洲云杉形 成层活动时间长, 但是生产效率低, 即采取了缓慢 生长但是风险比较大的生存策略, 相反, 后期演替 


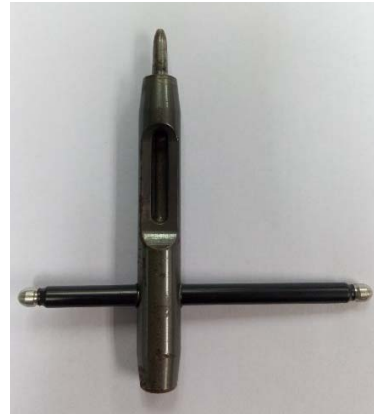

图1 微型生长雉。

Fig. 1 Trephor.

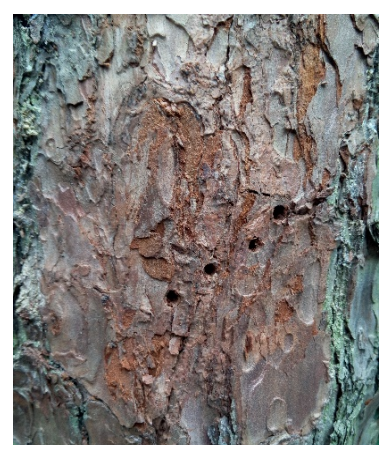

图2 微树芯方法取样后树干采样区。

Fig. 2 A section of stem surface after sampling with Trephor.

树种欧洲赤松和Abies alba形成层活动时间短而生 产效率高, 采取了密集生长、安全性较大的策略 (Cuny et al., 2012)。Xiao等(2014)通过监测中国黑河 下游的多枝柽柳(Tamarix ramosissima)木质部生长 过程, 发现径向生长和地下水深度显著相关, 因为 柽柳属于地下水湿生植物, 可以通过很长的根系吸 收地下水从而满足植物的生长需求。另外, 通过微 树芯技术可以回顾树木细胞面对气候变化做出的数 量、形态和结构上的调整, 可以弥补通过树木年轮 不能进行短期观察的缺陷, 同时在微观角度上为树 木的分类提供依据(Campbell et al., 2016), 进一步 丰富了传统树轮学(Fonti et al., 2015)。运用微树芯 技术还可以监测形成层向外产生的并且在运输有机 物中发挥重要作用的树木韧皮部生长(Jyske et al.,
2015)。近些年来，创新性地将微树芯技术用于监测 树木根部(Thibeault-Martel et al., 2008; Krause et al., 2010)的生长动态，将树木地上和地下不同部位的 生长进行整合加以分析, 能够从整体上更好地理解 树木的生长机制。由于微树芯技术的迅猛发展, 2005 年10月, “第一届树木生长季内形成过程分析研讨 会” (Intra-Annual Analysis of Wood Formation)在意 大利举行, 探讨了探索树木形成的监测方法和科学 产出, 对木质部发育的动态研究具有里程碑的意 义。贺敏慧和杨保(2014)综述了欧洲高海拔地区等 不同生态环境下利用微树芯技术研究树木形成层和 木质部生长物候以及与气候因子的关系, 并且通过 不同树龄、海拔以及健康状况等专题论述了微树芯 技术在评估树木生长对气候变化响应机制方面的广 泛应用。朱良军等(2017)综述了树木木质部在细胞 水平上的解剖特征如管胞密度、大小, 细胞壁厚度, 导管大小及密度等与环境变化的关系, 从而为研究 树木生长对气候变化做出的适应过程以及响应策略 提供了内在机理性的解释, 为本领域的研究人员提 供了重要的参考。近年来, 利用微树芯技术在定性 和定量树木初级生长和次级生长关系的研究, 利用 模型预测树木形成层和木质部发育过程对全球环境 变化以及当前生物地球化学循环的适应性和在树木 细胞水平上精准评估森林碳汇上取得新进展, 本文 将对以上研究成果进行总结, 作为对前人综述的完 善和补充, 希望为该领域未来研究提供一定的参考。

\section{1 树木初级生长和次级生长及其关系探讨}

树木生长分为初级生长和次级生长, 初级生长 是由初生分生组织细胞分化和生长所引起的植物器 官的生长, 主要包括生长季内芽、枝、叶的生长和 根系的衍生等; 次级生长为加粗生长, 是形成层通 过向内分裂不断产生新的细胞，经过细胞增大、细 胞壁加厚直至成熟等阶段，最终成为木质部(图3)。

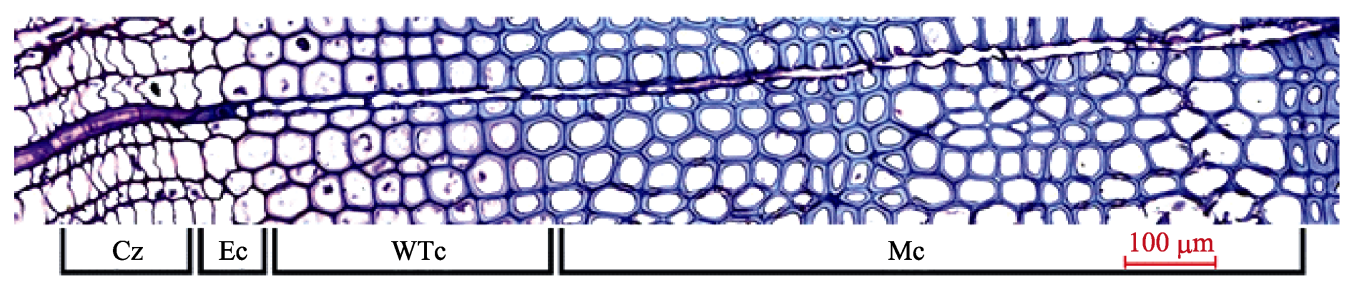

图3 广东鼎湖山国家自然保护区马尾松形成层以及不同发育阶段的木质部细胞。 $\mathrm{Cz}$, 形成层细胞; $\mathrm{Ec}$, 增大期细胞; WTc, 增 厚期细胞; $\mathrm{Mc}$, 成熟期细胞。

Fig. 3 Cambial and xylem cells at different development phases in Pinus massoniana in Dinghushan National Nature Reserve. Cz, cambial zone; Ec, enlarging cells; WTc, wall Thickening cells; Mc, mature cells. 
形成层细胞分裂的起始时间、终止时间, 形成层和 木质部细胞个数等都可以反映树木年内径向的生长 动态, 并且决定了木材的蓄积量, 对碳汇有重要作 用。树木的初级生长和次级生长是相互联系的过程。 Dufour和Morin (2010)通过研究加拿大魁北克Picea mariana的生长情况证明管胞生长的开始和结束时 间和前一年芽原基的形成、芽的成熟以及休眠时期 的环境有关。Morel等(2015)发现在热带雨林中, 叶 的物候可以用来很好地预估形成层活动。普遍认为, 春天芽产生的生长素向下运输刺激木质部开始生长 (Larson, 1969), 叶产生的光合作用产物为茎干生长 提供能量, 水分通过茎干向上运输。在生长季内同 时详细监测和调研树木的初级生长和次级生长, 并 探讨它们之间的相互协调关系及其与环境胁迫的关 系, 可以进一步阐明树木内在生理机制以及对全球 变化的适应性。过去因为技术问题, 形成层曾被称 为“了解得最少的植物分生组织” (Groover, 2005)。 通过微树芯技术, 可以监测形成层的动态生长过程, 结合初级生长物候, 将树木的初级生长和次级生长 动态有效地结合起来研究。

Rossi等(2009)在意大利详细监测并对比了一个 生长季内 3 个优势针叶树种欧洲落叶松 (Larix decidua)、Pinus cembra和欧洲云杉枝和叶的生长以及 树干木质部形成的过程, 发现这 3 个树种树干木质 部的开始生长都先于叶和枝条的生长, 并且第一个 晚材细胞的次生细胞壁的增厚均发生在叶和枝条的 生长结束之后。Zhai等(2012)通过监测加拿大东部的 北方森林生态系统中 3 个优势树种 (阔叶树种 Populus tremuloides和Betula papyrifera, 针叶树种 北美短叶松 (Pinus banksiana)) 在一个生长季内的 枝、叶、芽的生长和木质部的形成过程, 首次定量 了初级生长和次级生长之间的联系, 发现Populus tremuloides 和北美短叶松木质部的生长先于发芽, Betula papyrifera则反之。Michelot等(2012)通过观察 对比法国东南部温带森林中针叶树种欧洲赤松和两 个阔叶树种——欧洲山毛榉(Fagus sylvatica)和Quercus petraea一的生长情况, 发现欧洲赤松和 Quercus petraea在发芽之前木质部开始生长, 而欧 洲山毛榉的木质部生长在发芽之后, 并且在叶成熟 的时候生长速率达到最大值。这些研究结果表明无 论是针叶树种还是阔叶树种, 初级生长与次级生长 之间的协调性在很大程度上因种而异, 体现了不同
树种的不同器官对不同的环境产生的适应性。

传统观点认为, 春天树木茎干开始生长, 很有 可能是芽内储存的生长素向下运输刺激形成层恢复 活动(Fukuda, 2004)。然而Li等(2016)通过监测青藏 高原上急尖长苞冷杉(Abies georgei var. smithii)茎干 不同高度处的形成层分裂活动, 发现不论是幼树还 是成年树, 距离树冠的高度不会影响茎干形成层活 动, 说明春天树冠的嫩芽产生的生长素向下很快传 输到树干不同高度从而诱导形成层细胞同时分裂, 同时也说明㓞皮部能够高效传输分裂需要的大量碳 水化合物到植株的不同器官。Oribe等(2003)通过微 树芯技术对常绿针叶林Abies sachalinensis处于休眠 期的形成层和开始活动的形成层分别进行局部加热, 认为自然恢复活动的形成层细胞分裂以及分化的程 度取决于形成层附近组织中的淀粉含量。

Deslauriers等(2009)首次研究了加杨(Populus canadensis)和Populus deltoids在生长季内木质部的产生 和可利用性碳的关系, 证明形成层内的非结构性碳 含量和木质部的形成过程正相关, 即当木质部生长 速率最大时非结构性碳浓度较高, 而树木的初级生 长和次级生长都需要能量的供应, Antonucci等(2015) 发现芽开始生长的物候和木质部开始分化的时间具 有同步性, 说明树木在生长季开始的时候可能存在 着内部资源的竞争。树木内部可能存在一个最佳的 自我调节机制, 从而在生长季内同时合理分配光合 产物和已经储藏的非结构碳以用于不同器官的生长 (Huang et al., 2014)。例如发芽之前木质部形成的主 要能量源于前一年储藏的非结构碳, 而发芽后的主 要能量源于新的光合作用产物。Huang等(2014)沿海 拔高度对魁北克地区的Picea mariana和Abies balsamea 的初级生长和次级生长进行定量研究, 发现 加拿大东部寒带针叶树的木质部形成与芽的物候、 枝和叶的生长存在定量关系, 首创性地通过初级生 长和次级生长之间的数学关系连通了物候模型领 域和森林生态系统生产力和碳循环模型领域, 对 于树木初级生长和次级生长及其关系探讨具有重 要意义。

\section{2 气候变化背景下树木的应对机制}

根据IPCC (2013)报告, 近年来全球平均表面温 度升高, 大气中的温室气体 $\mathrm{CO}_{2} 、 \mathrm{CH}_{4}$ 和 $\mathrm{N}_{2} \mathrm{O}$ 浓度显 著增加, 降水格局发生改变并且极端事件发生频率 
增大。在气候变化的背景下, 树木木质部发育过程 受到威胁和改变。

\section{1 温度上升}

近年来随着气温的增高, 树木春天叶展开时间 提前, 秋天叶变色时间延迟, 导致了生长季延长, 从而产生更多的光合产物(Davi et al., 2011), 提高 了森林生产力(Tegel et al., 2014)。大量研究指出, 气 候变暖也引起了树干形成层活动和木质部生长的提 前且木质部生长季延长(Deslauriers et al., 2003, 2008; Rossi et al., 2013)。在1998-2000年的连续监测 中, Deslauriers等(2003)发现加拿大东部Abies balsamea木质部暖年(1999年)开始生长时间要早于冷 年; 在意大利东部阿尔卑斯山, Rossi等(2007)监测 对比了3个树种2002-2004年木质部生长过程, 发现 2003 年暖春的韧皮部活动开始时间要早于其他 2 年; Huang等(2011)沿着纬度梯度研究加拿大西部魁北 克地区Picea mariana的年内树干木质部的生长, 发 现春季低纬度林分木质部开始生长时间普遍比高纬 度林分早, 且暖年(即暖春和暖夏)林分的木质部生 长量多于暖春冷夏的木质部生长量, 因此形成宽年 轮, 反之形成窄年轮。另外通过建立模型可以进一 步定量形成层活动时间的变化。例如Lugo等(2012) 发现1950-2010年间加拿大东部Picea mariana的形 成层活动每 10 年提前 $0.5-0.8$ 天。Rossi等(2016)通过 研究北半球广阔的空间尺度、多个针叶树种的树干 木质部生长动态, 发现木质部物候的开始时间与年 平均气温呈线性正相关关系, 且木材形成的持续时 间随样点年平均气温的升高以 6.5 天 $\cdot{ }^{\circ} \mathrm{C}^{-1}$ 的速率线 性增长。此发现表明, 针叶林木材形成过程的高度 一致性以及春季 4-5月的温度是诱导木质部生长的 关键气候因子, 预示着在全球变暖的趋势下, 北半 球寒带森林的木材生长期可能会随温度的升高而同 步延长。

\section{2 干旱}

水分对于维持细胞膨压起着重要作用, 直接影响 形成层的细胞分裂以及木质部发育(Zweifel et al., 2006; Vieira et al., 2015)。干早通过影响树木的木质 部形成过程以及木材结构导致局部地区森林出现严 重衰退现象。研究表明, 干旱期间, 树木会通过调整 形成层活动开始和结束的时间即生长季长度等来适 应环境的改变。Gruber等(2010)通过监测奥地利阿尔 卑斯河谷中不同水分条件下欧洲赤松的年内生长过
程，发现干旱地区树木生长结束时间比半湿润地区 树木提前 4 个星期, 并且干旱地区的树木早材细胞 较小, 显示了干旱对细胞生长的制约。Ren等(2015) 通过微树芯技术监测了2009-2011年半干旱地区青 藏高原祁连圆柏(Juniperus przewalskii)木质化过程, 首次证明当温度适宜时, 降雨是启动形成层活动开 始的关键因子, 并且干旱导致木质部细胞减少, 木 质化过程提前结束, 在极干旱的条件下树木会延迟 木质化过程。另外, 干旱降低了西班牙东北部半干 旱地区Pinus halepensis的径向生长量, 并且对早材 的影响更严重(Pasho et al., 2012)。2003年干旱期间, 荷兰东部欧洲山毛榉和夏柇(Quercus robur)均停止 生长, 然而干旱过后, 仅欧洲山毛榉恢复生长, 说 明即使是在相同的生境下, 不同树种的抗旱性也存 在差异(van der Werf et al., 2007)。

干旱情况下, 树木会关闭气孔减少蒸腾从而降 低光合作用, 不利于光合产物的积累从而对树木生 长产生不利影响(Chaves et al., 2009)。通过微树芯技 术可以监测树木在短时间内的植物固碳机制以及碳 分配用于维持生长和存储的策略。Deslauriers等 (2016) 通过研究在不同温度和水分处理下 Picea mariana幼苗树干形成层每周细胞分裂和木质部形 成过程, 并且监测了形成层和木质部中的非结构碳 组分含量, 发现在形成层分裂活动中, 水分是主要 限制因子, 而在木质部细胞壁增厚过程中, 碳是主 要限制因子。该研究首次精细区分了碳和水在木质 部形成(包括分生组织活动和细胞壁增厚)中的交 互作用并阐明了干旱抑制树木生长及死亡的生理 机制。

\section{3 碳、氮增肥效应}

工业革命以来, 全球大气 $\mathrm{CO}_{2}$ 浓度迅速增加。实 验表明, $\mathrm{CO}_{2}$ 对树木的生长有直接的施肥效应以及 间接的增温效应, 从而在一定程度上增加植物的光 合效率、水分利用效率和地上-地下生物量, 进而促 进森林生态系统的碳循环(Huang et al., 2007)。同时, $\mathrm{CO}_{2}$ 浓度增加会影响木质部的细胞特性, 如细胞管 腔面积、细胞壁厚度等(Kostiainen et al., 2004)。然 而, $\mathrm{CO}_{2}$ 对树木生长影响的研究还停留在宏观尺度 上(个体和群落等), 用微树芯技术从微观尺度进一 步研究 $\mathrm{CO}_{2}$ 对木质部生长动态的影响还鲜有报道, 因此需要进一步加强这方面的研究。

另外, 近年来随着工业化的日益加剧, 氮沉降 
已经成为一个不容忽视的环境问题。Vitousek和 Howarth (1991)研究表明, 短期内有效氮的增加在 一定程度上促进了植物的光合作用, 而过量的氮 会导致土壤环境、植物体内营养元素失衡等从而影 响树木的能量供应(Roelofs et al., 1985)。在氮元素 缺乏的北方针叶林中, 氮沉降预期会促进树木的 生长。然而, 利用微树芯技术对加拿大 Picea mariana进行的土壤增温和加氮处理的实验表明, 树木木质部的形成物候并没有受到显著影响, 对 照组和加氮组的Picea mariana产生的细胞数量也 没有显著差异, 说明人们可能高估了氮添加对北 方森林生产力的影响(Lupi et al., 2012; D’Orangeville et al., 2013; Dao et al., 2015)。Zhang等(2017) 发现 3 年短期的低氮 $\left(25 \mathrm{~kg} \cdot \mathrm{hm}^{-2} \cdot \mathrm{a}^{-1}\right)$ 添加对暖温带 森林中的马尾松形成层活动和木质部的形成动态 并无显著影响。因此, 氮沉降对树木生长的影响还 需要更长时间的监测。目前, 我国已经成为全球氮 沉降三大地区之一, 南方地区作为氮饱和地区, 氮 沉降对树木木质部形成物候的研究还鲜有报道, 相关工作亟需开展。

全球变化的背景下, 各种气候因子并不单一影 响树木生长。各种气候因子、非气候因子以及人为 干扰之间交互影响陆地森林生态系统, 产生促进的 或者是相反的作用, 从而对树木的生长产生更为复 杂的综合影响。因此, 需要进一步加强气候变化背 景下不同因子对树木生长的综合影响研究, 从而全 面地评估树木对全球变化的适应能力。例如, 青藏 高原林线处树木生长通常被低温所限制, 温度升高 可能促使林线上移, 然而最新研究表明, 物种之间 的竞争在很大程度上抵消了温度升高的作用, 减缓 了林线上移的速度(Liang et al., 2016)。

\section{3 详细评估森林生态系统碳储存}

森林生态系统吸收并存储 $\mathrm{CO}_{2}$, 其碳汇功能可 以有效地减缓温室效应。全球变化的背景下, 随着 气候变暖和 $\mathrm{CO}_{2}$ 浓度的增高, 树木的生长过程正在 改变, 可能使得森林生态系统的固碳作用进一步加 强(Rossi et al., 2013)。全球变化下准确评估森林生 产力与碳储量是前沿课题, 树干木质部物候被普遍 认为是对环境变化非常敏感的指标之一, 因此定量 木质部物候与气候间的互作关系能够有效地评价全 球变化下森林的生长、生产力和碳储量。
传统方法是通过测量树干胸径、树高等来估测 森林碳汇。然而基于北半球微树芯方法获得的海量 数据开展的最新研究表明, 生长季内树干径向尺寸 停止增大后一个月内, 树木仍然在固碳(Cuny et al., 2015)。这正好可以解释目前基于碳通量塔所不能解 释的一些现象, 如秋天树木胸径停止生长后出现碳 的净增(Granier et al., 2008)以及在短的时间尺度上 生态系统净生产力与树木胸径大小的变化无显著关 系(Zweifel et al., 2010)。造成滞后的原因可能是, 在 木质部细胞完成细胞增大阶段后紧接着细胞壁增厚, 进一步导致固碳量的增加, 而树木的胸径并不会变 化。这说明通过在木质部形成过程中估算碳, 能提 高估测碳汇的准确性。Rossi等(2011)基于对Picea mariana在连续7年内形成层物候的分析, 建立了可 以预测全球变暖背景下的木质部活动的开始时间、 结束时间和持续时间变化的模型。其预测结果对森 林固碳能力具有重要的指示性作用。相比于利用传 统方法即通过独立的初级生长(枝、叶、根生物量) 和次级生长(地上生物量、年轮宽度或生长曲线)来 预测森林碳汇, Huang等(2014)建立了定量初级生长 和次级生长关系的混合效应模型, 该模型预期有助 于提高森林生态系统长短期碳储量和碳平衡预测的 准确性。

\section{4 树木微树芯技术的发展前景}

传统树木年轮学的研究方法多局限于年际间 树木地上部分径向生长的研究, 与之相比, 利用微 树芯技术, 结合物候观测, 可阐明树木次级生长和 初级生长的关系, 将树木作为一个有机整体联系起 来, 从而在更精细的时间尺度上更好地探索树木内 在的生理调节机制。另外, 将传统树木年轮学方法 (长时间尺度的年轮水平)和微树芯技术(短时间尺度 的细胞水平)相结合, 能更好地理解环境信号对树 木径向生长的影响以及树木内在的生理过程对外界 环境的响应。但目前微树芯技术的应用还不够广泛, 未来的研究应扩大微树芯技术的应用领域, 扩大研 究树种以及研究区域, 并将细胞水平、器官水平、 个体水平以及群落水平相结合。同时, 运用微树芯 技术研究全球变化背景下树木初级生长和次级生长 的响应可以为更准确地预测和评估森林生态系统的 生产力和碳平衡, 以及制定全球碳减排计划提供科 学数据和理论依据。 
基金项目 国家自然科学基金(31570584)和中国科 学院百人计划项目(Y421081001)。

\section{参考文献}

Antonova GF, Stasova VV (1993). Effects of environmental factors on wood formation in Scots pine stems. Trees, 7, 214-219.

Antonucci S, Rossi S, Deslauriers A, Lombardi F, Marchetti M, Tognetti R (2015). Synchronisms and correlations of spring phenology between apical and lateral meristems in two boreal conifers. Tree Physiology, 35, 1086-1094.

Bigler C, Gričar J, Bugmann H, Čufar K (2004). Growth patterns as indicators of impending tree death in silver fir. Forest Ecology and Management, 199, 183-190.

Campbell G, Rabelo GR, Cunha MD (2016). Ecological significance of wood anatomy of Alseis pickelii Pilg. Schmale (Rubiaceae) in a tropical dry forest. Acta Botanica Brasilica, 30, 124-130.

Chaves MM, Flexas J, Pinheiro C (2009). Photosynthesis under drought and salt stress: Regulation mechanisms from whole plant to cell. Annals of Botany, 103, 551-560.

Cuny HE, Rathgeber CB, Frank D, Fonti P, Fournier M (2014). Kinetics of tracheid development explain conifer tree-ring structure. New Phytologist, 203, 1231-1241.

Cuny HE, Rathgeber CBK, Frank D, Fonti P, Mäkinen H, Prislan P, Rossi S, del Castillo EM, Campelo F, Vavrčík H, Gričar J, Gryc V, Luis MD, Vieira J, Čufar K, Kirdyanov AV, Oberhuber W, Treml V, Huang JG, Li XX, Swidrak I, Deslauriers A, Liang EY, Nöjd P, Gruber A, Nabais C, Morin H, Krause C, King G, Fournier M (2015). Woody biomass production lags stem-girth increase by over one month in coniferous forests. Nature Plants, 1, 15160. doi: 10.1038/nplants.2015.160.

Cuny HE, Rathgeber CB, Lebourgeois F, Fortin M, Fournier M (2012). Life strategies in intra-annual dynamics of wood formation: Example of three conifer species in a temperate forest in north-east France. Tree Physiology, 32, 612-625.

D’Orangeville L, Houle D, Côté B, Duchesne L, Morin H (2013). Increased soil temperature and atmospheric N deposition have no effect on the $\mathrm{N}$ status and growth of a mature balsam fir forest. Biogeosciences, 10, 4627-4639.

Dao MC, Rossi S, Walsh D, Morin H, Houle D (2015). A 6-year-long manipulation with soil warming and canopy nitrogen additions does not affect xylem phenology and cell production of mature black spruce. Frontiers in Plant Science, 6, 877. doi: 10.3389/fpls.2015.00877.

Davi H, Gillmann M, Ibanez T, Cailleret M, Bontemps A, Fady B, Lefèvre F (2011). Diversity of leaf unfolding dynamics among tree species: New insights from a study along an altitudinal gradient. Agricultural and Forest Meteorology, 151, 1504-1513. del Castillo EM, Longares LA, Gričar J, Prislan P, Gil-Pelegrín E, Čufar K, de Luis M (2016). Living on the edge: Contrasted wood-formation dynamics in Fagus sylvatica and Pinus sylvestris under Mediterranean conditions. Frontiers in Plant Science, 7, 370. doi: 10.3389/fpls.2016.00370.

Deslauriers A, Giovannelli A, Rossi S, Castro G, Fragnelli G, Traversi L (2009). Intra-annual cambial activity and carbon availability in stem of poplar. Tree Physiology, 29, 1223-1235.

Deslauriers A, Huang JG, Balducci L, Beaulieu M, Rossi S (2016). The contribution of carbon and water in modulating wood formation in black spruce saplings. Plant Physiology, 170, 2072-2084.

Deslauriers A, Morin H, Urbinati C, Carrer M (2003). Daily weather response of balsam fir (Abies balsamea (L.) Mill.) stem radius increment from dendrometer analysis in the boreal forests of Québec (Canada). Trees, 17, 477-484.

Deslauriers A, Rossi S, Anfodillo T, Saracino A (2008). Cambial phenology, wood formation and temperature thresholds in two contrasting years at high altitude in southern Italy. Tree Physiology, 28, 863-871.

Dong MY, Jiang Y, Yang HC, Wang MC, Zhang WT, Guo YY (2012). Dynamics of stem radial growth of Picea meyeri during the growing season at the treeline of Luya Mountain, China. Chinese Journal of Plant Ecology, 36, 956964. (in Chinese with English abstract) [董满宇, 江源, 杨 浩春, 王明昌, 张文涛, 郭媛媛 (2014). 芦芽山林线白 杆生长季径向生长动态. 植物生态学报, 36, 956-964.]

Drew DM, Downes GM (2009). The use of precision dendrometers in research on daily stem size and wood property variation: A review. Dendrochronologia, 27, 159-172.

Dufour B, Morin H (2010). Tracheid production phenology of Picea mariana and its relationship with climatic fluctuations and bud development using multivariate analysis. Tree Physiology, 30, 853-865.

Eilmann B, Zweifel R, Buchmann N, Pannatier EG, Rigling A (2011). Drought alters timing, quantity, and quality of wood formation in Scots pine. Journal of Experimental Botany, 62, 2763-2771.

Fonti P, Tabakova MA, Kirdyanov AV, Bryukhanova MV, von Arx G (2015). Variability of ray anatomy of Larix gmelinii along a forest productivity gradient in Siberia. Trees, 29, $1165-1175$.

Fukuda H (2004). Signals that control plant vascular cell differentiation. Nature Reviews Molecular Cell Biology, 5, 379-391.

Gou XH, Deng Y, Chen FH, Yang MX, Fang KY, Gao LL, Yang T, Zhang F (2010). Tree ring based streamflow reconstruction for the Upper Yellow River over the past 1234 years. Chinese Science Bulletin, 55, 4179-4186.

Granier A, Bréda N, Longdoz B, Gross P, Ngao J (2008). Ten years of fluxes and stand growth in a young beech forest at 
Hesse, North-eastern France. Annals of Forest Science, 64, 704. doi: 10.1051 /forest:2008052.

Groover AT (2005). What genes make a tree a tree? Trends in Plant Science, 10, 210-214.

Gruber A, Strobl S, Veit B, Oberhuber W (2010). Impact of drought on the temporal dynamics of wood formation in Pinus sylvestris. Tree Physiology, 30, 490-501.

He MH, Yang B (2014). A research overview in detecting tree radial growth using the microcoring method. Journal of Desert Research, 34, 1133-1142. (in Chinese with English abstract) [贺敏慧, 杨保 (2014). 使用微树芯方法监测 树木径向生长变化的研究综述. 中国沙漠, 34, 11331142.]

Huang JG, Bergeron Y, Denneler B, Berninger F, Tardif J (2007). Response of forest trees to increased atmospheric $\mathrm{CO}_{2}$. Critical Reviews in Plant Sciences, 26, 265-283.

Huang JG, Bergeron Y, Zhai LH, Denneler B (2011). Variation in intra-annual radial growth (xylem formation) of Picea mariana (Pinaceae) along a latitudinal gradient in western Québec, Canada. American Journal of Botany, 98, 792800 .

Huang JG, Deslauriers A, Rossi S (2014). Xylem formation can be modeled statistically as a function of primary growth and cambium activity. New Phytologist, 203, 831-841.

IPCC (Intergovernmental Panel on Climate Change) (2013). Climate Change 2013: The Physical Science Basis. Cambridge University Press, Cambridge, UK.

Jyske TM, Suuronen JP, Pranovich AV, Laakso T, Watanabe U, Kuroda K, Abe H (2015). Seasonal variation in formation, structure, and chemical properties of phloem in Picea abies as studied by novel microtechniques. Planta, 242, 613-629.

Kostiainen K, Kaakinen S, Saranpää P, Sigurdsson BD, Linder S, Vapaavuori E (2004). Effect of elevated $\left[\mathrm{CO}_{2}\right]$ on stem wood properties of mature Norway spruce grown at different soil nutrient availability. Global Change Biology, 10, 1526-1538.

Krause C, Rossi S, Thibeault-Martel M, Plourde PY (2010). Relationships of climate and cell features in stems and roots of black spruce and balsam fir. Annals of Forest Science, 67, 402. doi: 10.1051/forest/2009122.

Larson PR (1969). Wood Formation and the Concept of Wood Quality. https://www.fs.fed.us/nrs/pubs/other/1969/nc_1969_ larson_001.pdf. Cited: 2017-01-17.

Li XX, Camarero JJ, Case B, Liang EY, Rossi S (2016). The onset of xylogenesis is not related to distance from the crown in Smith fir trees from the southeastern Tibetan Plateau. Canadian Journal of Forest Research, 46, 885889.

Liang EY, Wang YF, Piao SL, Lu XM, Camarero JJ, Zhu HF, Zhu LP, Ellison AM, Ciais P, Peñuelas J (2016). Species interactions slow warming-induced upward shifts of tree- lines on the Tibetan Plateau. Proceedings of the National Academy of Sciences of the United States of America, 113, 4380-4385.

Lugo JB, Deslauriers A, Rossi S (2012). Duration of xylogenesis in black spruce lengthened between 1950 and 2010 . Annals of Botany, 110, 1099-1108.

Lupi C, Morin H, Deslauriers A, Rossi S, Houle D (2012). Increasing nitrogen availability and soil temperature: Effects on xylem phenology and anatomy of mature black spruce. Canadian Journal of Forest Research, 42, 1277-1288.

Lupi C, Rossi S, Vieira J, Morin H, Deslauriers A (2014). Assessment of xylem phenology: A first attempt to verify its accuracy and precision. Tree Physiology, 34, 87-93.

Mäkinen H, Nöjd P, Saranpää P (2003). Seasonal changes in stem radius and production of new tracheids in Norway spruce. Tree Physiology, 23, 959-968.

Mäkinen H, Seo JW, Nöjd P, Schmitt U, Jalkanen R (2008). Seasonal dynamics of wood formation: A comparison between pinning, microcoring and dendrometer measurements. European Journal of Forest Research, 127, 235-245.

Mann ME, Zhang Z, Hughes MK, Bradley RS, Miller SK, Rutherford S, Ni F (2008). Proxy-based reconstructions of hemispheric and global surface temperature variations over the past two millennia. Proceedings of the National Academy of Sciences of the United States of America, 105, 13252-13257.

Michelot A, Simard S, Rathgeber C, Dufrêne E, Damesin C (2012). Comparing the intra-annual wood formation of three European species (Fagus sylvatica, Quercus petraea and Pinus sylvestris) as related to leaf phenology and non-structural carbohydrate dynamics. Tree Physiology, 32, 1033-1045.

Morel H, Mangenet T, Beauchêne J, Ruelle J, Nicolini E, Heuret P, Thibaut B (2015). Seasonal variations in phenological traits: Leaf shedding and cambial activity in Parkia nitida Miq. and Parkia velutina Benoist (Fabaceae) in tropical rainforest. Trees, 29, 973-984.

Oribe Y, Funada R, Kubo T (2003). Relationships between cambial activity, cell differentiation and the localization of starch in storage tissues around the cambium in locally heated stems of Abies sachalinensis (Schmidt) Masters. Trees, 17, 185-192.

Pasho E, Camarero JJ, Vicente-Serrano SM (2012). Climatic impacts and drought control of radial growth and seasonal wood formation in Pinus halepensis. Trees, 26, 18751886.

Ren P, Rossi S, Gricar J, Liang EY, Cufar K (2015). Is precipitation a trigger for the onset of xylogenesis in Juniperus przewalskii on the north-eastern Tibetan Plateau? Annals of Botany, 115, 629-639.

Roelofs JGM, Kempers AJ, Houdijk AF, Jansen J (1985). The effect of air-borne ammonium sulphate on Pinus nigra var.

www.plant-ecology.com 
maritima in the Netherlands. Plant and Soil, 84, 45-56.

Rossi S, Anfodillo T, Čufar K, Cuny HE, Deslauriers A, Fonti P, Frank D, Gričar J, Gruber A, Huang JG, Jyske T, Kašpar J, King G, Krause C, Liang EY, Mäkinen H, Morin H, Nöjd P, Oberhuber W, Prislan P, Rathgeber CBK, Saracino A, Swidrak I, Treml V (2016). Pattern of xylem phenology in conifers of cold ecosystems at the Northern Hemisphere. Global Change Biology, 22, 3804-3813.

Rossi S, Anfodillo T, Menardi R (2006). Trephor: A new tool for sampling microcores from tree stems. Iawa Journal, 27, 89-97.

Rossi S, Deslauriers A, Anfodillo T, Carraro V (2007). Evidence of threshold temperatures for xylogenesis in conifers at high altitudes. Oecologia, 152, 1-12.

Rossi S, Isla E, Martínez-García A, Moraleda N, Gili JM, Rosell-Melé A, Arntz WE, Gerdes D (2013). Transfer of seston lipids during a flagellate bloom from the surface to the benthic community in the Weddell Sea. Scientia Marina, 77, 397-407.

Rossi S, Morin H, Deslauriers A, Plourde PY (2011). Predicting xylem phenology in black spruce under climate warming. Global Change Biology, 17, 614-625.

Rossi S, Rathgeber CB, Deslauriers A (2009). Comparing needle and shoot phenology with xylem development on three conifer species in Italy. Annals of Forest Science, 66, 1-8.

Seo JW, Eckstein D, Jalkanen R, Schmitt U (2011). Climatic control of intra- and inter-annual wood-formation dynamics of Scots pine in northern Finland. Environmental and Experimental Botany, 72, 422-431.

Shao XM, Xu Y, Yin ZY, Liang EY, Zhu HF, Wang SZ (2010). Climatic implications of a 3585-year tree-ring width chronology from the northeastern Qinghai-Tibetan Plateau. Quaternary Science Reviews, 29, 2111-2122.

Speer JH (2010). Fundamentals of Tree-Ring Research. University of Arizona Press, Tucson, USA.

Tegel W, Seim A, Hakelberg D, Hoffmann S, Panev M, Westphal T, Büntgen U (2014). A recent growth increase of European beech (Fagus sylvatica L.) at its Mediterranean distribution limit contradicts drought stress. European Journal of Forest Research, 133, 61-71.

Thibeault-Martel M, Krause C, Morin H, Rossi S (2008). Cambial activity and intra-annual xylem formation in roots and stems of Abies balsamea and Picea mariana. Annals of Botany, 102, 667-674.

van der Werf GW, Sass-Klaassen UG, Mohren GMJ (2007). The impact of the 2003 summer drought on the intraannual growth pattern of beech (Fagus sylvatica L.) and oak (Quercus robur L.) on a dry site in the Netherlands. Dendrochronologia, 25, 103-112.

Vieira J, Campelo F, Rossi S, Carvalho A, Freitas H, Nabais C (2015). Adjustment capacity of maritime pine cambial activity in drought-prone environments. PLOS ONE, 10, e0126223. doi: 10.1371/journal.pone.0126223.

Vitousek PM, Howarth RW (1991). Nitrogen limitation on land and in the sea: How can it occur? Biogeochemistry, 13, 87-115.

Wang SZ, Zhao XH (2013). Re-evaluating the Silk Road's Qinghai Route using dendrochronology. Dendrochronologia, 31, 34-40.

Wang XC, Song LP, Zhang YD (2011). Climate-tree growth relationships of Pinus sylvestris var. mongolica in the northern Daxing'an Mountains, China. Chinese Journal of Plant Ecology, 35, 294-302. (in Chinese with English abstract) [王晓春, 宋来萍, 张远东 (2011). 大兴安岭北部 樟子松树木生长与气候因子的关系. 植物生态学报, 35 , 294-302.]

Wolter KE (1968). Notes: A new method for marking xylem growth. Forest Science, 14, 102-104.

Wu XD (1990). Tree Ring and Climate Change. China Meteorological Press, Beijing. (in Chinese) [吴祥定 (1990). 树 木年轮与气候变化. 气象出版社, 北京.]

Xiao SC, Xiao HL, Peng XM, Tian QY (2014). Intra-annual stem diameter growth of Tamarix ramosissima and association with hydroclimatic factors in the lower reaches of China's Heihe River. Journal of Arid Land, 6, 498-510.

Yang B, Qin C, Wang JL, He MH, Melvin TM, Osborn TJ, Briffa KR (2014). A 3,500-year tree-ring record of annual precipitation on the northeastern Tibetan Plateau. Proceedings of the National Academy of Sciences of the United States of America, 111, 2903-2908.

Yu J, Xu QQ, Liu WH, Luo CW, Yang JL, Li JQ, Liu QJ (2016). Response of radial growth to climate change for Larix olgensis along an altitudinal gradient on the eastern slope of Changbai Mountain, Northeast China. Chinese Journal of Plant Ecology, 40, 23-35. (in Chinese with English abstract) [于健, 徐倩倩, 刘文慧, 罗春旺, 杨君 珑, 李俊清, 刘琪璟 (2016). 长白山东坡不同海拔长白 落叶松径向生长对气候变化的响应. 植物生态学报, 40 , 23-35.]

Zalamea PC, Sarmiento C, Stevenson PR, Rodriguez M, Nicolini E, Heuret P (2013). Effect of rainfall seasonality on the growth of Cecropia sciadophylla: Intra-annual variation in leaf production and node length. Journal of Tropical Ecology, 29, 361-365.

Zhai LH, Bergeron Y, Huang JG, Berninger F (2012). Variation in intra-annual wood formation, and foliage and shoot development of three major Canadian boreal tree species. American Journal of Botany, 99, 827-837.

Zhang JZ, Gou XH, Zhao ZQ, Liu WH, Zhang F, Cao ZY, Zhou FF (2014). Improved method of obtaining microcore paraffin sections in dendroecological research. Chinese Journal of Plant Ecology, 37, 972-977. (in Chinese with English abstract) [张军周, 勾晓华, 赵志千, 刘文 火, 张芬, 曹宗英, 周非飞 (2014). 树轮生态学研究中 
微树芯石蜡切片制作的方法探讨. 植物生态学报, 37, 972-977.]

Zhang S, Huang JG, Rossi S, Ma Q, Yu B, Zhai L, Luo D, Guo X, Fu S, Zhang W (2017). Intra-annual dynamics of xylem growth in Pinus massoniana submitted to an experimental nitrogen addition in Central China. Tree Physiology, (in Press) doi: 10.1093/treephys/tpx079.

Zhu LJ, Li ZS, Wang XC (2017). Anatomical characteristics of xylem in tree rings and its relationship with environments. Chinese Journal of Plant Ecology, 41, 238-251. (in Chinese with English abstract) [朱良军, 李宗善, 王晓春 (2017). 树轮木质部解剖特征及其与环境变化的关系.
植物生态学报, 41, 238-251.]

Zweifel R, Eugster W, Etzold S, Dobbertin M, Buchmann N, Häsler R (2010). Link between continuous stem radius changes and net ecosystem productivity of a subalpine Norway spruce forest in the Swiss Alps. New Phytologist, 187, 819-830.

Zweifel R, Zimmermann L, Zeugin F, Newbery DM (2006). Intra-annual radial growth and water relations of trees: Implications towards a growth mechanism. Journal of Experimental Botany, 57, 1445-1459.

特邀编委: 张齐兵 责任编辑: 李 敏

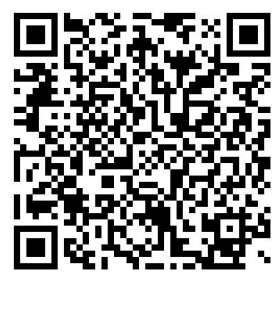

